\title{
PERAN STAKEHOLDER DALAM PENGEMBANGAN KAWASAN MASJID KUNO BAYAN BELEQ SEBAGAI DESTINASI WISATA WARISAN BUDAYA
}

\author{
Jodi Hariawan ${ }^{1}$,Yusri Abdillah ${ }^{2}$, Luchman Hakim $^{3}$ \\ Fakultas Ilmu Administrasi, Universitas Brawijaya, Malang, Indonesia ${ }^{12}$ \\ Fakultas Matematika dan Ilmu Pengetahuan Alam, Universitas Brawijaya, Malang, Indonesia ${ }^{3}$ \\ Email : jodihariawan@gmail.com ${ }^{1}$, yusriabdillah@ub.ac.id ${ }^{2}$, luchman@ub.ac.id $\underline{3}$
}

\begin{abstract}
Area of Masjid Kuno Bayan Beleq located in the Lombok island. Development in this sites area involves the tourism stakeholders consisting of government, private sector, and the local community. The purpose of this study were to identify the profile and tourism attractions, the role of stakeholders, and the supporting and inhibiting factors of stakeholder roles. This research applies descriptive qualitative method. Literature studies, observations, and interviews are the technique used to obtain the data needed. The result shows that area of Masjid Kuno Bayan Beleq has the potential of cultural heritage tourism. The development of this area that has been done include: (1) the development of tourist atrraction, accesibility and amenity. (2) the role of stakeholder include : local government, private sector and local community. The stakeholders roles include the provision of infrastructure, human resource development, local development and promotion. Supporting factors are the involvement of local communities in the management and support of the Non Government organiztion. Inhibiting factors are Department of culture and tourism roles is not maximized, local communities as a professional tour players are still lacking, and there are no investors who investing for development of the sites area and lack of coordination from various stakeholders.
\end{abstract}

Keywords : Cultural Heritage, Tourism Development, Stakeholder, area of Masjid Kuno Bayan Beleq

\begin{abstract}
ABSTRAK
Kawasan Masjid Kuno Bayan Beleq merupakan salah satu peninggalan situs cagar budaya yang terletak di kecamatan Bayan Kabupaten Lombok Utara. Pengembangan kawasan ini melibatkan beberapa stakeholder yang terdiri dari pemerintah, swasta dan masyarakat. Penelitian ini bertujuan untuk mengindentifikasi profil daya tarik wisata, peran stakeholder pariwisata, dan menganalisis faktor pendukung dan penghambat. Metode yang digunakan dalam penelitian ini yaitu metode deskriptif kualitatif dengan teknik pengumpulan data melalui studi pustaka, observasi, dan wawancara. Hasil penelitian menunjukkan bahwa kawasan Masjid Kuno Bayan Beleq berpotensi untuk dikembangkan menjadi kawasan wisata warisan budaya. Pengembangan kawasan Masjid Kuno Bayan Beleq yang telah dilakukan meiputi (1) pengembangan atraksi, aksesibilitas dan amenitas (2) peran stakeholder pariwisata yang terdiri dari pemerintah daerah, pelaku usaha pariwisata, dan masyarakat lokal setempat. Peran stakeholder dalam pengembangan ini berupa penyediaan sarana prasarana, pembinaan sumber daya manusia, pemberdayaan masyarakat lokal dan promosi. Faktor pendukung pengembangan kawasan ini adalah keterlibatan masyarakat lokal terutama yang tergabung dalam kelompok sadar wisata Sugriwa dalam pengelolaan dan dukungan pihak swasta dalam hal ini lembaga non-profit. Faktor penghambat pengembangannya yaitu peran Dinas Kebudayaan dan Pariwisata yang masih belum maksimal, masyarakat lokal sebagai pelaku wisata belum profesional, belum adanya investor swasta yang melirik pengembangan kawasan dan kurangnya koordinasi dari berbagai stakeholder.
\end{abstract}

Kata Kunci : Warisan Budaya, Pengembangan Pariwisata, Stakeholder, Kawasan Masjid Kuno Bayan Beleq 


\section{PENDAHULUAN}

Pariwisata merupakan salah satu sektor penting yang menjadi perhatian serius pemerintah dikarenakan pertumbuhannya sangat berpengaruh terhadap peningkatan devisa dan laju perkembangan nasional. Menurut Zendratno (2014) dalam menghadapi persaingan secara internasional. Peran pemerintah sebagai pelaku dan fasilitator dipandang sangat perlu untuk menjamin terlaksananya pembangunan dan pengembangan kepariwisataan yang berkelanjutan dengan mengikut sertakan peran para pelaku pembangunan (stakeholder) di sektor ini, dengan demikian akan tercipta produk wisata yang berdaya saing tinggi. Pariwisata sebagai suatu industri bidang jasa mempunyai banyak keterkaitan dengan sektor ekonomi lainnya, yaitu keterkaitan ke belakang, baik dengan sektor industri maupun dengan sektor lainnya. Dengan demikian apabila wisatawan melakukan kunjungan perjalanan wisata ke suatu destinasi, maka keberadaanya selama berkegiatan akan mempengaruhi kondisi perekonomian di daerah destinasi tersebut (Weaver dan Oppermann, 2000)

Salah satu tren berwisata saat ini adalah jenis pariwisata budaya. Wisata budaya merupakan kecendrungan baru di kalangan wisatawan yang mulai berkembang menjadi fenomena global. UNWTO (2004) mengakui sektor pariwisata budaya sebagai sektor pariwisata global yang berkembang sangat pesat. Berdasarkan klaim ini, diperkirakan ada 450 juta perjalanan wisatawan internasional tercatat pada tahun 2014. Hal ini dilandasi oleh adanya trend baru bagi wisatawan untuk mencari suatu yang unik dan autentik dari suatu kebudayaan di suatu destinasi yang akan dikunjungi (Ardika, 2015), budaya menjadi motivasi penting yang mempengaruhi destinasi pilihan wisatawan. Berdasarkan hal ini, budaya semakin menjadi alat untuk pemasaran dan tujuan branding wisata suatu daerah. Oleh karena itu, sektor pariwisata budaya merupakan salah satu aktivitas pertumbuhan utama di masa depan dari permintaan pasar pariwisata global. Selain itu, menurut Marimin (2016) keuntungan dalam pengembangan pariwisata warisan budaya ada tiga yaitu : (1) Keuntungan ekonomi (ketersediaan lapangan kerja, keragaman lapangan kerja, dan peningkatan pendapatan rumah tangga dan anggaran daerah), (2) Keuntungan fisik (pelestarian bangunan bersejarah dan warisan budaya), pengembangan infrastruktur, konservasi alam dan ekosistemnya), dan (3) Keuntungan sosial (popularitas bagi masyarakat di sekitarnya, peningkatan upaya untuk mempertahankan nilainilai budaya lokal, peningkatan kebanggaan publik, semakin besar peluang untuk pendidikan tinggi, dan pemahaman yang lebih besar dari orang-orang tentang diri mereka sendiri). Kondisi bangunan merupakan obyek utama yang mendasari daya tarik wisata berbasis warisan budaya karena keunikan bangunan dan bentuk fisiknya menjadi identifikasi yang sekaligus membedakan dengan daerah tujuan wisata lainnya (Shankar et.al, 2015). Oleh karena itu, kondisi bangunan yang masih asli menjadi potensi kuat untuk pengembangan kepariwisataan berbasis warisan budaya.

Pengembangan kepariwisataan di Kabupaten Lombok Utara didukung dengan jenis potensi wisata yang ada seperti kondisi alam yang indah dan warisan budaya yang masih terjaga lengkapnya dengan kearifan lokal yang masih di lestarikan. Salah satu objek wisata di Kabupaten Lombok Utara yang memiliki potensi untuk dikembangkan lebih lanjut menjadi destinasi unggulan yaitu kawasan "Masjid Kuno Bayan Beleq". Potensi perkembangan sector pariwisata di kawasan ini nantinya bisa berdampak positif bagi kesejahteraan masyarakat sekitar dan peningkatan pendapatan asli daerah. Kawasan Masjid Kuno Bayan Beleq ini memiliki potensi berupa situs cagar budaya masjid kuno, enam buah cangkup makam ulama, rumah tradisional masyarakat adat karang bajo, hutan adat yang masih lestari, persawahan warga model tersering, kolam pemandian mandala serta lengkap dengan atraksi kebudayaan dan kearifan lokal yang masih terjaga di kawasan ini sehingga wisatawan bisa dengan langsung merasakan pengalaman hidup dengan tata cara kehidupan tradisional masyarakat adat bayan yang unik dan autentik. Selain itu, kawasan ini didukung bersebelahan dengan dua destinasi unggulan daerah yaitu lokasi kawasan wisata Senaru yang terlebih dahulu terkenal dengan destinasi wisata alam air terjun Sendang Gile dan pintu masuk Taman Nasional Gunung Rinjani yang merupakan salah satu spot pegunungan favorit para pendaki. Selain itu kedua kawaan ini mempunyai banyak pilihan akomodasinya. Berdasarkan potensi yang ada, kawasan Masjid Kuno Bayan Beleq ini sangat layak untuk dikembangkan 
menjadi destinasi wisata warisan budaya unggulan di Kabupaten Lombok Utara.

Menurut Budiwanti (2000) pertumbuhan pariwisata menempatkan masyarakat adat Bayan berhadap-hadapan dengan dunia yang lebih luas, yang pada akhirnya mempengaruhi mereka menjadi lebih terbuka dengan orang asing/luar dengan latar belakang budaya yang berbeda. Terlihat dari minat generasi muda yang tinggi untuk mengangkat nilai filosofi leluhur berupa ikut serta berpartisipasi dalam atraksi ritual adat dalam suatu acara kegiatan. Namun, pengembangan wisata di kawasan Masjid Kuno Bayan Beleq saat ini masih belum maksimal terlihat dari tingkat kunjungan wisatawan hanya ramai pada saat event tertentu seperti ketika ada event Maulid adat, Lebaran adat ataupun event lain yang diadakan masyarakat sekitar. Selain itu, dari segi prasarana penunjang wisata belum memadai seperti kawasan Masjid Kuno dan Rumah tradisionalnya membutuhkan pemugaran total agar kawasan ini tidak terkesan kumuh dan menarik untuk dikunjungi wisatawan. Kondisi sarana atau fasilitas penunjang pariwisata dikawasan ini terbilang cukup lengkap walaupun dengan kondisi seadanya. Beberapa sarana yang sudah ada di tempat ini seperti warung, penginapan, tempat ibadah, toilet. Untuk daya tarik wisata lainnya terdapat pula kolam pemandian Mandala, kegiatan menenun secara tradisional oleh perempuan adat setempat yang apabila semua dikemas secara menarik dan sedemikian rupa akan menambah daya tarik kawasan tersebut. Akibat pengelolaan yang kurang maksimal, beberapa atraksi tersebut hanya ramai ketika moment tertentu saja.

Pembangunan pariwisata di suatu daerah khususnya di Kabupaten Lombok Utara membutuhkan adanya kontribusi kerjasama dan kolaborasi dari para stakeholder atau pemangku kepentingan pariwisata. Menurut Freeman dan McVea (2001) stakeholder adalah setiap kelompok atau individu yang dapat mempengaruhi atau dipengaruhi oleh pencapaian tujuan organisasi. Ada tiga stakeholder kepariwisataan yang sangat berperan penting dalam pengembangan suatu destinasi pariwisata yaitu Pemerintah, Swasta dan Masyarakat. Menurut Widodo (2015) peran stakeholder diperlukan untuk mengoptimalkan pelaksanaan pembangunan pariwisata suatu daerha. Salah satu stakeholder yang berperan dalam pembangunan pariwisata adalah pemerintah daerah namun memiliki keterbatasan yakni (1) keterbatasan finansial; (2) keterbatasan teknis; (3) keterbatasan kejangkauan program, dengan demikian peran stakeholder eksternal (swasta, masyarakat) dibutuhkan agar tujuan pengembangan suatu destinasi dapat terwujud. Peran stakeholder sangat penting dalam pengembangan kawasan Masjid Kuno Bayan Beleq, karena pemerintah daerah saat ini sedang giatnya menggalakan situs warisan budaya sebagai daya tarik utama wisatawan berkunjung ke Kabupaten Lombok Utara. Terbukti setiap event nasional atau internasional atraksi warisan budaya masyarakat adat Bayan digunakan sebagai promosi terdepan ikon pariwisata daerah. Namun, terkenalnya kawasan destinasi ini sebagai ikon daerah tidak sejalan dengan jumlah kunjungan wisatawan yang cenderung sepi dari kunjungan wisatawan harian dan selain itu juga, kurangnya perhatian dari stakeholder sehingga fasilitas pengelolaan menjadi tidak maksimal serta kualitas sumber daya manusia (masyarakat lokal) dan kepariwisataan masih kurang professional. Maka dari itu diperlukan suatu solusi agar masing-masing stakeholder dapat berperan maksimal dan permasalahan-permasalahan yang ada dapat terealisasikan. Penelitian in berfokus pada konsep pengembangan 3A (Atraksi, Aksesibilitas dan Amenitas) Peran Stakeholder Dalam Pengembangan Kawasan Masjid Kuno Bayan Beleq Sebagai Destinasi Wisata Warisan Budaya.

\section{KAJIAN PUSTAKA \\ Pariwisata}

Murphy (1985) memaknai pariwisata adalah bagian keseluruhan dari komponenkomponen terkait seperti wisatawan, destinasi wisata, perjalanan, industri dan lain lain yang merupakan akibat dari perjalanan wisata ke destinasi wisata. Sepanjang perjalanan tersebut diakukan sementara waktu. Berdasarkan pengertian tersebut maka dapat dijelaskan bahwa pariwisata adalah suatu kegiatan yang dilakukan perorangan atau berkelompok, dengan tujuan untuk mencari kepuasan dengan cara menikmati keindahan alam dan budaya dari satu tempat ke tempat lain dan tidak bersifat menetap.

Jenis-jenis objek wisata menurut Sammeng (2001), antara lain:

1. Objek Wisata Budaya

2. Objek Wisata Alam 


\section{Objek Wisata Minat Khusus}

Berdasarkan jenisnya kawasan Masjid Kuno Bayan Beleq termasuk wisata budaya yang mengandalkan potensi warisan budaya dan kearipan lokal sebagai atraksi budaya. Sillberbeg dalam Damanik (2013) yang memaknai parwisata budaya sebagai kunjungan wisatawan dari luar destinasi yang didorong oleh ketertarikan pada objek-objek atau peninggalan sejarah, seni, ilmu pengetahuan dan gaya hidup yang dimiliki oleh kelompok, masyarakat, daerah ataupun lembaga. Warisan budaya dianggap sebagai modal budaya untuk mengembangkan pariwisata budaya. Keberadaan pariwisata adalah salah satu fenomena budaya global. Pariwisata adalah sistem yang umumnya terdiri dari tiga komponen, yaitu wisatawan, elemen geografis, dan industri pariwisata. Wisata budaya juga dapat memberikan keuntungan ekonomi (pendapatan) kepada masyarakat setempat, termasuk dana dan pendidikan untuk tujuan restorasi atau pelestarian warisan budaya, baik yang nyata (tangible) maupun yang intangible atau tidak nyata satu (Marimin, 2016).

\section{Konsep Pariwisata Budaya}

Pariwisata budaya memiliki konsep definisi yang beragam dari berbagai ahli. Hal ini disesuaikan dengan tujuan dan kepentingan masing-masing. menurut MC Kercher dan Du Cross dalam Damanik (2013) memaknai pariwisata budaya sebagai bentuk pariwisata minat khusus (special interest tourism), dimana motivasi utama pengunjung untuk melakukan wisata adalah budayanya itu sendiri. Definisi yang lain lagi dikemukakan oleh Sillberbeg dalam Damanik (2013) yang memandang pariwisata budaya sebagai kunjungan orang dari luar destinasi yang diakibatkan oleh ketertarikan mereka pada objekobjek atau peninggalan sejarah, kesenian, ilmu pengetahuan dan gaya hidup yang dimiliki oleh kelompok, masyarakat, daerah ataupun lembaga. Sedangkan Menurut (Keyser, 2002) Pariwisata budaya mengarahkan perjalanan wisata yang meyediakan keuntungan langsung bagi wisatawan terhadap pengalaman-pengalaman selama berwisata baik itu dalam berkesenian, mengunjungi tempat historikal, musik, adat/tradisi lokal, festival, atraksi budaya masyarakat lokal selama berwisata. Menurut (Marimin, 2016) Warisan budaya dianggap sebagai modal suatu budaya setempat untuk mengembangkan pariwisata budaya. Keberadaan pariwisata adalah salah satu tren budaya global. Pariwisata adalah sistem yang umumnya terdiri dari tiga elemen, yaitu wisatawan, komponen geografis, dan industri pariwisata. Wisata budaya juga dapat memberikan keuntungan ekonomi (pendapatan) kepada masyarakat lokal, termasuk dana dan pendidikan pelatihan untuk tujuan restorasi atau pelestarian warisan budaya, baik yang nyata maupun yang tidak nyata satu. Timothy dan Nyaupane (2009) menyebutkan bahwa pariwisata budaya biasanya bergantung kepada komponen hidup atau terbentuk dari budaya dan mengarah kepada penggunaan masa lampau yang nyata dan tidak nyata sebagai bagian riset pariwisata. Hal tersebut meliputi budaya yang ada sekarang, yang diturunkan dari masa lampau, pusaka non-material seperti musik, tari, bahasa, agama, kuliner, tradisi artistik dan festival dan pusaka material seperti lingkungan budaya terbangun termasuk monumen, katredal, museum, bangunan bersejarah, kastil, reruntuhan arkeologi dan relik.

\section{Pengembangan Pariwisata}

Pada dasarnya ada beberapa elemen yang harus dipenuhi agar pengembangan wisata disuatu daerah dapat berjalan dengan baik. Parameter obyek wisata yang baik menurut (Yoeti,1997) untuk menjadi tempat wisata yang baik hingga tercapainya industri wisata tergantung pada tiga $\mathrm{A}$ (3A), yaitu

1. Daya tarik wisata (Attractions) yang meliputi daya tarik utama pada kekayaan alam, budaya maupun buatan, seperti event yang sering disebut wisata minat khusus (special interest).

2. Mudah dicapai (Accesibility) yang mencakup dukungan sistem transportasi pada suatu destinasi yang meliputi : ketersediaan jalur transportasi seperti jalan raya, jembatan, terminal, bandara, pelabuhan dan moda transportasi lain.

3. Amenitas (amenity) Yaitu yang mencakup fasilitas penunjang dan pendukung kegiatan wisata di destinasi yang meliputi : akomodasi penginapan, warung/rumah makan, retail, took cinderamata, penukaran uang asing, agen perjalanan, pusat informasi wisata, dan fasilitas kenyamanan lainnya. 


\section{Stakeholder Pariwisata}

Menurut Freeman dan McVea (2001) stakeholder adalah setiap orang atau badan yang dapat mempengaruhi atau dipengaruhi oleh pencapaian dalam tujuan suatu organisasi. Sedangkan menurut Gonslaves dalam Iqbal (2007) mendeskripsikan stakeholder atas siapa yang memberi dampak kebijakan, program, dan aktivitas pembanguna. Mereka bisa laki-laki atau perempuan, komunitas, kelompok sosial ekonomi, atau lembaga dalam berbagai dimensi pada setiap tingkat golongan masyarakat. Setiap kelompok ini memiliki sumber daya dan kebutuhan masingmasing yang harus terwakili dalam proses pengambilan keputusan dalam kegiatan pembangunan. Dalam pengembangan kepariwisataan pada hakekatnya melibatkan tiga stakeholder yang saling terkait yaitu pemerintah, swasta, dan masyarakat ( Rahim, 2012). Masingmasing stakeholder memiliki peran dan fungsi yang berbeda agar pengembangan wisata disuatu daerah dapat berjalan dengan baik. Peran pemerintah dalam mengembangkan pariwisata adalah menyediakan infrastruktur, menambah berbagai fasilitas penunjang, kegiatan koordinasi dengan pemangku kepentingan lainnya, mengadakan event promosi kedaerah lain maupun keluar negeri. Pihak swasta sebagai pelaku bisnis mempunyai peran dalam menyediakan sarana pendukung pariwisata seperti akomodasi penginapan, restaurant, transportasi, paket wisata dan lain-lain. Sedangkan masyarakat sebagai pemilik dan pengelola kawasan wisata dapat menjadi bagian dari atraksi wisata untuk menarik wisatawan dengan cara mengenalkan kebudayaan dan kearifan lokal yang menjadi ciri khas dari suatu destinasi. Selain itu perguruan tinggi sangat berperan dalam pengembangan kepariwisataan suatu destinasi. Perguruan tinggi atau akademisi bertugas melakukan riset untuk pengembangan ilmu pengetahuan dan teknologi yang kemudian dihilirisasi melalui pengabdian masyarakat.

\section{METODE PENELITIAN}

Penelitian ini berlokasi di kawasan Masjid Kuno Bayan Beleq serta di Dinas Kebudayaan dan Pariwisata Kabupaten Lombok Utara. Kawasan situs ini diperuntukkan untuk pariwisata budaya sesuai dengan Perda Kabupaten Lombok Utara No.9 Tahun 2011 Tentang Rencana Tata Ruang dan Wilayah dalam pasal 25 ayat 1-2b. Penelitian ini merupakan jenis penelitian deskriptif dengan pendekatan kualitatif karena peneliti akan mendeskripsikan konsep pengembangan pariwisata 3A (Atraksi, Aksesibilitas, Amenitas) dan peran stakeholder kepariwisataan dalam pengembangan kawasan Masjid Kuno Bayan Beleq sebagai destinasi wisata warisan budaya di Kabupaten Lombok Utara. Fokus dari penelitian ini yaitu :

1. Konsep pengembangan pariwisata 3A (Atraksi, Aksesibilitas, Amenitas) di kawasan Masjid Kuno Bayan Beleq

2. Peran stakeholder kepariwisataan yang terdiri dari pemerintah daerah, swasta, masyarakat dan perguruan tinggi dalam melakukan pengembangan kawasan Masjid Kuno Bayan Beleq sebagai destinasi wisata warisan budaya di Kabupaten Lombok Utara.

Teknik pengumpulan data yang digunakan dalam penelitan adalah observasi, wawancara, dan dokumentasi, sedangkan instrument penelitian yang digunakan peneliti adalah pedoman wawancara, alat perekaman suara (recorder), kamera, dan alat tulis menulis. Sumber data diperoleh dari data primer melalui hasil observasi lapangan, metode wawancara digunakan menggunakan teknik purposive sampling dengan mencari seorang informan yang mengarahkan kepada informan-informan lain yang terkait ( snowball sampling). Informan pada penelitian ini terdiri dari Dinas Kebudayaan dan Pariwisata Kabupaten Lombok Utara, masyarakat local, swasta ( pemilik usaha penginapan, dan transportasi), Aliansi Masyarakat Adat Nusantara (AMAN), Non Government Organization (NGO), wisatawan, dan akademisi di bidang pariwisata. Data sekunder meliputi dokumen-dokumen dan arsip yang diperoleh melalui Dinas Kebudayaan dan Pariwisata Kabupaten Lombok Utara yang terkait dengan kepariwisataan Kabupaten Lombok Utara dan wisata warisan budaya khususnya bukubuku dan jurnal, internet yang memuat tentang peraturan perundang perundangan profil Kabupaten Lombok Utara. Analisis data yang digunakan oleh peneliti adalah model Miles dan Huberman. Menurut Miles dan Huberman (2013) pada penelitian kualitatif terdapat beberapa hal yang digunakan untuk menganalisis data yaitu pengumpulan data, kondensasi data, penyajian data 
dan penarikan kesimpulan. teknik pemeriksaan keabsahan data yang digunakan peneliti dalam penelitian ini adalah triangulasi sumber dan teknik. Triangulasi sumber dilakukan dengan cara mengecek data atau informasi yang diperoleh melalui wawancara dengan informan. Selanjutnya dat tersebut ditanyakan kepada informan lain yang masih terkait satu sama lain. Sedangkan triangulasi teknik peneliti melakukan pengecekan informasi antara hasil wawancara dengan dokumen lainnya.

\section{HASIL DAN PEMBAHASAN}

\section{Gambaran Umum Kawasan Masjid Kuno Bayan Beleq}

Masjid Kuno Bayan Beleq adalah salah satu situs cagar budaya dilindungi oleh Undangundang Nomor 11 tahun 2010 tentang cagar budaya. Situs ini merupakan salah satu benda cagar budaya masa peninggalan Islam lampau yang berada di Desa Karang Bajo, Kecamatan Bayan, Kabupaten Lombok Utara. Menurut sejarah, disekitar area situs Masjid Kuno Bayan Beleq juga terdapat enam buah makam para ulama penyebaran agama Islam yang terbuat dari bambu, rumah adat tradisional Karang Bajo, hutan adat dengan sistem persawahan terasering, dan kolam mata air Mandala disamping itu, di kawasan situs ini juga masih melestarikan kearifan lokalnya seperti ritual-ritual adat keagamaan : maulid adat, lebaran adat, ritual Ngasah Ngaponin Sesinggan, ritual pernikahan Tampah Wirang serta kegiatan menenun kain khas bayan sebagai salah satu penggerak roda perekonomian terutama untuk kaum perempuan, selain itu masyarakat lokal juga masih menjaga kelestarian lingkungan alam, hutan adat dan sumber mata air beserta awig-awig nya.

Dengan segala keunikannya tersebut pemerintah daerah Kabupaten Lombok Utara memasukkan kawasan ini sebagai destinasi pariwisata budaya sesuai dengan PERDA No.9 tahun 2011 tentang rencana tata ruang dan wilayah dalam pasal 25 ayat 1-2b. Masjid Kuno Bayan Beleq ini terletak pada titik koordinat $50 \mathrm{~L}$ 0436919, 9086170 UTM, dengan ketinggian 278 meter diatas permukaan air laut. Dengan batasbatas situs; sisi Utara : Rumah Adat Karang Bajo, Timur : Sawah, kebun, Selatan : Pemukiman, dan Barat : Jalan Raya Bayan. Seperti gambar dibawah ini

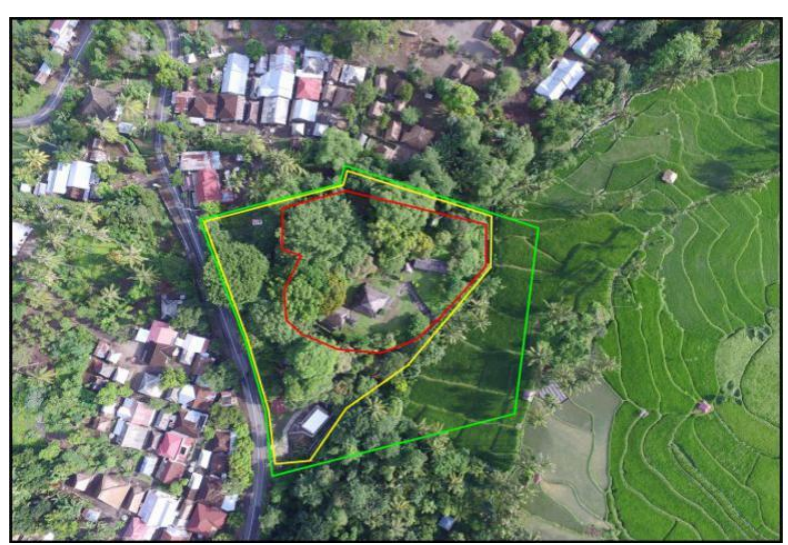

Gambar 1 : Situs Masjd Kuno Bayan Beleq

Sumber : Balai Pelestarian Cagar Budaya Bali (Tahun 2018)

Kawasan Masjid Kuno Bayan Beleq memiliki potensi dan daya tarik wisata yang sangat beragam dan sangat menarik apabila dikemas dengan sangat baik. Namun bebebrapa potensi wisata tersebut masih belum dikembangkan secara efektif oleh stakeholder setempat dikarenakan sumber daya manusia masih belum memadai. Berdasarkan wawancara peneliti dengan pengelola kawasan tersebut secara garis besar potensi tersebut dibagi menjadi dua yaitu : Pertama, potensi alam yang masih alami dan sejuk serta didukung oleh letak geografis yang dekat dengan Kawasan Wisata Senaru dengan keindahan Taman Nasional Gunung Rinjaninya, kolam pemandian Mandala yang langsung bersumber dari mata air pegunungan serta kawasan ini berhadapan langsung dengan hutan adat (persawahan) warga sekitar dengan konsep terasering yang sangat indah untuk dijadikan tempat berfoto. Kedua, adalah potensi warisan budaya, seperti yang kita ketahui Kawasan Masjid Kuno Bayan Beleq ini juga dikelilingi oleh rumah adat masyarakat dusun Karang Bajo yang masih terjaga lengkap dengan konsep kearifan lokal budayanya. Berbagai peninggalan sejarah tersebut diintegrasikan dengan atraksi budayanya dapat dikembangkan menjadi suatu atraksi wisata untuk menarik kunjungan wisatawan.

\section{Ketersediaan Aspek 3A Dalam Pengembangan Kawasan Situs Masjid Kuno Bayan Beleq}

Parameter obyek wisata yang baru menurut (Yoeti, 1994) untuk menjadi destinasi wisata yang baik hingga tercapainya industry pariwisata 
tergantung pada tiga A (3A), yaitu atraksi (attraction), mudah dicapainya (accessibility), dan fasilitas (amenities).

\section{1) Atraksi}

Kawasan situs Masjid Kuno Bayan Beleq merupakan salah satu destinasi wisata di Kabupaten Lombok Utara yang berbasis pada warisan budaya. Menurut Mill (2000 : 207), daya tarik wisata dapat ditinjau menjadi dua subjek yaitu : daya tarik inti dan daya tarik pendukung. Pada kawasan Masjid Kuno Bayan Beleq daya tarik intinya yaitu bangunan Masjid Kuno dan makam ulama serta rumah tradisional di sekelilingnya. Masjid Kuno ini sangat istimewa karena merupakan masjid pertama yang dibangun oleh ulama Gaus Abdul Razaq dan pengikutnya sebagai bukti sejarah lokasi pertama penyebaran agama islam di pulau Lombok. Kawasan ini sangat ramai diziarahi pengunjung atau wisatawan ketika acara Maulid Nabi pada bulan Rabiul awal yang dilakukan secara adat, masyarakat berbondongbondong datang dari seluruh pulau Lombok untuk mengikuti tradisi tersebut sehingga oleh pemerintah daerah dibuatkan event mauled adat guna mendatangkan wisatawan karena terdapat berbagai macam atraksi budaya selama prosesinya. Wisata edukasi yang ditawarkan adalah proses kegiatan menenun kain songket dan pernak pernik lainnya secara tradisional yang masih dilestarikan oleh kelompok perempuan adat. Hasilnya diapakai untuk setiap kegaiatan adat dan dijual untuk cinderamata

Sedangkan daya tarik pendukung kawasan Masjid Kuno Bayan Beleq juga memiliki atraksi yang menarik seperti didalam event mauled adat terdapat atraksi yang dapat melibatkan langsung wisatawan seperti arak-arakan praja mauled, pembersihan beras di hutan adat, adu tarung Peresian, pembersihan benda pusaka. Seperti yang ditunjukkan oleh Gambar 2

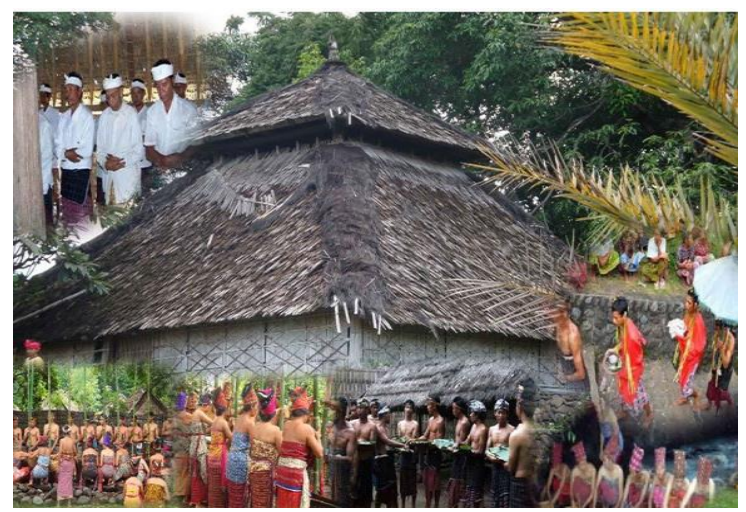

Gambar 2. Prosesi Mauled Adat Bayan

Sumber : dokumentasi peneliti dan pokdarwis Sugriwa tahun 2018 (dimodifikasi)

Selanjutnya daya tarik pendukung lainnya yaitu kolam pemandian Mandala yang bersumber dari mata air Gunung Rinjani, wisata arum jeram di sungai Munjid, kegiatan camping di bukit Gol Munjid dan spot selfie di balai adat Sebaya Tanta yang diinisiasi oleh kelompok sadar wisata setempat.

\section{2) Aksesibilitas}

Akses/sarana yang dapat memudahkan wisatawan menuju lokasi destinasi wisata yaitu sarana transportasi, terminal, pelabuhan, bandara, petunjuk arah jalan dan lain-lain. Akses bandara terdekat yaitu Bandara Internasional Lombok yang berada di Kabupaten Lombok Tengah. Jarak tempuh dari bandara menuju lokasi kawasan situs memakan waktu hampir tiga jam. Sedangkan pelabuhan terdekat yaitu Bangsal yang merupakan pintu masuk resmi kawasan tiga Gili berjarak tempuh satu jam perjalanan. Sedangkan akses dari ibukota provinsi melalui Terminal Bertais. Namun masih belum adanya transportasi khusus menuju lokasi kawasan situs sehingga wisatawan lebih mudah menggunakan jasa biro perjalanan menuju lokasi. Aksesibilitas lain seperti jalan raya sudah cukup memadai dengan jalan yang sudah di cor aspal menyerupai jalan tol sehingga berbagai macam kendaraan dengan mudah menuju ke kawasan situs. 
Selain itu, petunjuk arah di setiap persimpangan sudah cukup terpasang.

\section{3) Amenitas}

Aspek amenitas kawasan Masjid Kuno Bayan Beleq sudah cukup tersedia namun masih minim sehingga perlu adanya pengembangan dari pihak stakeholder. Ketersediaan akomodasi penginapan sudah tersedia, wisatawan yang ingin merasakan pengalaman unik ketika mengunjungi kawasan situ bisa menginap dan menyewa rumah adat tradisional warga sekitar di kawasan masjid kuno bayan beleq. Sedangkan untuk penginapan modern seperti homestay, villa dan hotel, wisatawan bisa menginap di Kawasan Wisata Senaru yang lebih lengkap fasilitas akomodasi dan berjarak tempuh sekitar 10 menit berkendara. Selain akomodasi penginapan, restoran atau warung makan yang menjual kukiner khas daerah akan menjadi nilai tersendiri bagi wisatawan. Berdasarkan data dari Dinas Kebudayaan dan Pariwisata Kabupaten Lombok Utara (2019) menyebutkan terdapat tujuh rumah makan berizin yang menjual makan tradisional/kuliner khas maupun makanan lainnya.

Komponen amenitas lainnya yang penting dalam pengembangan kawasan situs Masjid Kuno Bayan Beleq adalah biro perjalanan wisata terutama yang menawarkan paket wisata lengkap seperti. Paket wisata Tiga Gili Plus Masjid Kuno atau paket wisata Pendakian Gunung Rinjani Plus Wisata Masjid Kuno. Jadi wisatawan yang berkunjung ke Kabupaten Lombok Utara tidak hanya menikmati wisata di kawasan Tiga Gili dan Kawasan Wisata Senaru saja yang berbasis alam dan bahari namun juga diperkenalkan dengan jenis wisata alternatif yaitu wisata warisan budaya Masjid Kuno Bayan Beleq. Aspek amenitas lainnya yang perlu dikembangkan lagi seperti ketersediaan bank yang dilengkapi penukaran uang dan ATM, pusat informasi wisata dan lain-lain. Pusat informasi wisata hanya berada di Kawasan Wisata Senaru sebagai pintu masuk Kawasan Taman Nasional Gunung Rinjani. Sehingga wisatawan yang berkunjung ke kawasan situs tanpa menggunakan jasa pihak ketiga akan kebingungan dalam mendapatkan informasi wisata.

\section{Peran stakeholder}

\section{Pemerintah}

1. Penyediaan sarana dan prasarana atau infrastruktur destinasi

a. Rehabilitasi Gerbang masuk di kawasan destinasi Masjid Kuno Bayan Beleq

b. Pembangunan toilet umum untuk wisatawan

c. Rehabilitasi rumah adat tradisional Karang Bajo

2. Pengembangan kapabilitas Sumber Daya Manusia lokal dengan cara mengadakan pelatihan-pelatihan hospitality, kepemanduan, pelatihan ketrampilan membuat souvenir dan workshop untuk meningkatkan pemahaman dan pengetahuan masyarakat setempat sebagai pelaku pariwisata langsung.

3. Mengadakan promosi-promosi pariwisata memperkenalkan kawasan destinasi Masjid Kuno Bayan Beleq dengan segala atributnya di setiap pameran pariwisata atau event bertema budaya.

\section{Swasta}

1. Aliansi Masyarakat Adat Nusantara cabang Kabupaten Lombok Utara

a. Memberikan pelatihan dan modal bantuan bagi ibu-ibu penenun kain khas adat di kawasan MKBB

b. Mengadakan workshop tentang sadar wisata bagi masyarakat sekitar

2. Pengusaha jasa transportasi, menyediakan transportasi, penyewaan mobil atau motor untuk memperlancar aksesibilitas dari bandara kota Mataram, senggigi atau bangsal Gili menuju kawasan masjid Kuno Bayan Beleq.

3. Trash Hero Cabang Bayan : lembaga nonprofit dengan keanggotaan para pemuda setempat bekerjasama dengan 'Saifana Organic Farm" perusahaan agrowisata setempat milik wisatawan asing berasal dari switzerland mengadakan kegiatan clean-up kawasan situs setiap hari jumat, mengedukasi anak-anak lokal dengan memberikan pelatihan bahasa inggris serta program zero waste pengolahan sampah plastik menjadi barang tepat guna. Selain itu terdapat juga peran pengusaha jasa 
transportasi dan agen travel dari kawasan wisata senaru yang menawarkan pilihan kepada wisatawan untuk melakukan kujungan wisata ke kawasan situs ini.

\section{Masyarakat}

1) Sebagai pengelola kawasan Masjid Kuno Bayan Beleq

2) Membuka usaha pendukung lainnya yang mendukung kegiatan pariwisata setempat seperti penginapan di rumah tradisional, warung, toko cinderamata, penyewaan river tubing dan alat mendaki gunung dan camping

3) Menjadi guide bagi wisatawan yang ingin menjelajahi kawasan Masjid Kuno Bayan Beleq dan yang ingin mendaki kawasan Gunung Rinjani

4) Mempromosikan kawasan Masjid Kuno Bayan Beleq dengan membuat paket wisata seperti : paket wisata maulid adat, paket wisata tampah wirang dengan melakukan promosi melalui sosial media.

Peran perguruan tinggi/ akademisi dalam hal ini beberapa institusi pendidikan di kota Mataram seperti Sekolah Tinggi Pariwisata (STP) Mataram, UIN Mataram, Universitas Mataram rutin mengirim mahasiswa atau akademisinya untuk melakukan pengabdian masyarakat melalui kegiatan Kuliah Kerja Nyata (KKN). study tour, pendidikan kepelatihan kepariwisataan dan hospitality, riset mengenai wisata budaya dan lain sebagainya.

\section{Faktor Pendukung}

1) Peran aktif masyarakat local serta kesadaran mereka daam mengelola kawasan Masjid Kuno Bayan Beleq : Partisipasi masyarakat langsung terlibat dalam mengelola kawasan situs, peran masyarakat setempat yaitu menyediakan sarana pariwisata dan melayani langsung wisatawan yang berkunjung, masyarakat local terutama pemuda juga antusias dalam setiap ritual adat yang diadakan-adakan seperti pembersihan kawasan Masjid, mata air, hutan adat pemilihan pengelola kawasan situs, ritual keagamaan dan membentuk kelompok sadar wisata Sugriwa

2) Daya tarik alam yang indah berupa hutan adat, kawasan pertanian (hutan adat) berjenis terasering, pemandangan alam Gunung Rinjani yang menakjubkan, kolam pemandian Mandala serta daya tarik budaya yang sangat khas dan autentik yang masih terjaga yaitu situs masjid kuno, makam ulama, rumah tradisional, kegiatan menenun tradisional, pertanian tradisional serta ritual adat budaya yang masih di lestarikan.

\section{Factor Penghambat}

1) Peran pemerintah daerah dalam hal ini Dinas kebudayaan dan Pariwisata Kabupaten Lombok Utara masih belum maksimal. Pemerintah daerah masih belum berinisiatif dalam mengembangkan kawasan Masjid Kuno Bayan Beleq ini sebagai jenis wisata alternative lainnya dikarenakan pemerintah daerah masih hanya terfokus dengan kawasan wisata Tiga Gili dan kawasan Wisata Senaru .Sehingga kawasan ini hanya ramai dikunjungi pada event tertentu saja

2) Belum adanya investor yang tertarik menanamkan modalnya untuk pengembangan Kawasan Masjid Kuno Bayan Beleq dikarenakan lokasi Kawasan Wisata Senaru yang sangat berdekatan lebih dahulu populer sehingga pembangunan dan pengembangan akomodasi lebih banyak terpusat di kawasan tersebut.

3) Kerjasama dan koordinasi antar stakeholder masih kurang sehingga kawasan Masjid Kuno Bayan Beleq ini hanya ramai pada saat-saat tertentu saja seperti lebaran adat dan mauled adat atau event tertentu lainnya. Pertama, pihak masyarakat dengan pihak pemerintah sering terjadi miss-komunikasi dan sering tidak adanya win-win solution ketika kedua pihak melakukan pertemuan. Kedua, antara masyarakat dan pihak swasta yaitu belum tertariknya investor untuk berinvestasi di kawasan ini sehingga tidak ada yang mendorong jiwa kreatifitas dan kewirausahaan masyarakat. Ketiga, antara pemerintah dan pihak swasta. Belum ada upaya pemerintah dalam mempromosikan kawasan ini kepada pihak swasta untuk pengembangan lebih lanjut.

\section{KESIMPULAN DAN SARAN \\ Kesimpulan}

Pemerintah melalui dinas kebudayaan dan pariwisata kabupaten Lombok utara sudah menetapkan kawasan Masjid Kuno Bayan Beleq sebagai kawasan pariwisata budaya sesuai dengan 
peraturan daerah dan telah melaksanakan program dan kegiatan pengembangan sarana dan prasarana, dumber daya manusia, dan promosi wisata. Kegiatan pengembangan yang telah direalisasikan adalah pembangunan gerbang masuk destinasi dan toilet umum, pemugaran rumah tradisional masyarakat adat sekitar, pembinaan masyarakat setempat melalui workshop, pelatihan ketrampilan serta promosi pada event pariwisata.

Keterlibatan pihak swasta dalam pengembangan kawasan Masjid Kuno Bayan Beleq yaitu memberikan pelatihan dan bantuan modal kepada kelompok ibu penenun kain khas adat serta pengusaha transportasi, menyediakan akses sewa mobil atau motor kekawasan ini.

Masyarakat terlibat dalam pengembangan kawasan sebagai pengelola dan membuka usaha pariwisata seperti warung, toko cindra mata, dan penginapan di rumah tradisioal serta beberapa kelompok masyarakat sudah memulai membuat paket wisata. Serta dari pihak perguruan tinggi negeri melalui mahasiswa dan tenaga pendidikannya sudah melakukan tri dharma perguruan tinggi.

\section{Saran}

Berdasarkan hasil penelitian di lapangan, maka saran yang dapat diberikan oleh peneliti yaitu:

Pemerintah Daerah

1. Dinas Kebudayaan Dan Pariwisata Kabupaten Lombok Utara Memaksimalkan kinerja dinas terkait dengan membuat kebijakan khusus terkait pengembangan pariwisata warisan budaya di kawasan Masjid Kuno Bayan Beleq. Seperti mengusulkan kawasan ini masuk dalam event kalendar pariwisata NTB, komodifikasi event mauled adat baik dari penataan destinasi selama acara, penambahan dan komodifikasi atraksi ataupun promosi secara massive baik melalui media massa ataupun elektronik

2. Perlu adanya sinergitas pengelolaan pariwisata antara pemerintah dengan pemangku kepentingan lainnya yang mengarah pada pemberdayaan masyarakat local. Diharapkan dinas terkait mampu menjalin kerjasama dan kemitraan dengan berbagai pihak seperti lembaga pariwisata asusiasi pengusaha travel, hotel, perbankan, media, pihak kampus dan sebagainya untuk mendukung organisasi penunjang wisata. Seperti mengundang investor untuk melakukan investasi dalam mengembangkan kolam pemandian Mandala, kegiatan arum jeram dan camping sehingga terlihat lebih menarik untuk dikunjungi. Selain itu pemerintah daerah mendorong hotel dan agen perjalan yang berada di kawasan Tiga Gili dan kawasan wisata Senaru untuk ikut membantu dan bekerjasama mempromosikan destinasi wisata warisan budaya ini.

3. Meningkatkan keahlian dan kualitas masyarakat lokal tentang kepariwisataan terutama dalam menejemen pengelolaan suatu destinasi melalui pelatihan, workshop atau sosialisasi.

4. Mengemas daya tarik yang ada dan membuat kalender event kegiatan wisata yang bias digunakan sebagai informasi untuk wisatawan dalam melakukan kunjungan di kawasan Masjid Kuno Bayan Beleq

Swasta

1. Aliansi Mayarakat Adat Nusantara (AMAN), Trash Hero Bayan dan Saifana Organic Farm semakin meningkatkan jalinan kerjasama dengan pemerintah untuk melakukan pembinaan terhadap masyarakat untuk meningkatkan kreativitas masyarakat dalam menciptakan usaha wisata, kepedulian terhadap lingkungan sekitar dan situs cagar budaya.

2. Pengusaha travel perlu melakukan kerjasama dengan masyarakat setempat dalam pembuatan paket wisata

3. Investor mulai mencoba melirik investasi dalam bidang pengembangan di luar zona inti bekerjasama dengan masyarakat lokal setempat seperti merevitalisasi kolam pemandian Mandala, wisata arum jeram, spot selfie, kegiatan camping dengan mengemas ulang sedemikian rupa dan menambah wahana baru, dikawasan Masjid Kuno Bayan Beleq

Masyarakat

1. Semakin meningkatkan kesadaran dan tanggung jawab dalam menjaga kelestarian situs cagar budaya beserta kearifan lokalnya sebagai warisan budaya

2. Mengoptimalkan kinerja kelompok sadar wisata dengan ikut berpartisipasi didalamnya 
3. Aktif dalam mengikuti pelatihan kepariwisataan maupun pembuatan usaha pariwisata,

\section{DAFTAR PUSTAKA}

Ardika, I Wayan. 2015. Warisan Budaya Perspektif Masa Kini. Denpasar: Udayana University Press

Balai Pelestarian Cagar Budaya Bali. 2018

Budiwanti, Erni. 2000. Islam Sasak : Wetu Telu Versus Wetu Lima. Jakarta : LKIS

Damanik, Phil Janianton. 2013. Pariwisata Indonesia :Antara Peluang Dan Tantangan. Yogyakarta :PustakaPelajar.

Freeman, R.E dan J. McVea. 2001. "a Stakeholder Approach To Strategic Management".http:/papers.ssrn.com/sol3/ papers.cfm?abstract_id=263511.SSRN. diakses tanggal 15 Juni 2019

Iqbal, Muhammad. 2007. Analisis Pemangku Kepentingan Dan Implementasinya Dalam Pembangunan Pertanian. Jurnal Litbang Pertanian, 26(3) : 89-99

Keyser, H. 2002, Tourism Development, University Press Publishers, Cape Town.

Marimin. 2016. Cultural Heritage As A Tourist Destination : A Focus On Surakarta Kasunan Palace In Indonesia. Bandung. ASERS Publishing.

Miles, B. Mattew dan Hubberman, A, Michael. Saldana, Johnny. 2013. Qualitative Data Analysis : A Methods Sourcebook: Edition 3. United States of Americas : SAGE Publications

Mill, Robert Christine. (2000). Tourism The International Bussiness. Jakarta: PT Grafindo Persada.

Murphy, P. E. 1985. Tourism A Community Approach. Metheun. New York.

Peraturan Daerah Kabupaten Lombok Utara No.9 Tahun 2011 Tentang Rencana Tata Ruang Dan Wilayah
4. Selalu berkoordinasi dengan pemangku kepentingan lainnya terkait keberlanjutan arah pengembangan destinasi wisata

Pitana I Gde, Diarta, I Ketut SuryaDiarta, (2009) Pengantar Ilmu Pariwisata.Edisi I Yogyakarta: Andi Offset

Rahim, F. 2012. Pedoman Pokdarwis. Jakarta: Direktur Jenderal Pengembangan Destinasi Pariwisata Kementrian Pariwisata dan Ekonomi Kreatif

Sammeng, A.M. 2001. Cakrawala Pariwisata. Jakarta: PT Gramedia Pustaka Umum

Shankar, S. 2015. Impact Of Heritage Tourism In India: A Case Study. International Journal OfInnovative

Timothy, D. J., \& Nyaupane, G. P. 2009. Cultural Heritage And Tourism In The Developing World: A Regional Perspective. Routledge Taylor \&Francis Group.DOI: $1.4324 / 9780203877753$

Undang-Undang No.11 Tahun 2010 Pemanfaatan Benda Cagar Budaya

UNWTO. 2004. Indicators Of Sustainable Development For Tourism Destinations, A Guidebook. United Nations World Tourism Organization.Madrid, Spain.

Weaver, David Bruce \& Oppermann, Martin. 2000. Tourism Management. Australia : John Wiley \& Sons.

Widodo, Teguh. 2015. Pembangunan Endogen (Mengabaikan Peran Negara Dalam Pembangunan), Yogyakarta : Penerbit Deepublish

Yoeti, Oka A. 1994. Pengantar Ilmu Pariwisata. Angkasa. Bandung.

Yoeti, Oka A. 1997. Perencanaan Dan Pengembangan Pariwisata. Jakarta : Pradnya Paramita.

Zendratno, Samudra K. 2014. Kebudayaan dan Pariwisata Nias. Jakarta : Mitra Wacana Media 